\title{
Strategi Marketing Politik Kepala Desa Pertahana Pada Pilkades Di Desa Sidomukti Kecamatan Dendang Kabupaten Tanjung Jabung Timur
}

\author{
Cholillah Suci Pratiwi $^{1}$, Faizah Bafadhal ${ }^{2}$, Ade Siska Giovani ${ }^{3}$ \\ ${ }^{1}$ Dosen Prodi Ilmu Politik Universitas Jambi \\ ${ }^{2}$ Dosen Fakultas Hukum Universitas Jambi \\ ${ }^{3}$ Mahasiswa Prodi Ilmu Politik Universitas Jambi \\ 드olillahsucipratiwi@yahoo.com, ${ }^{2}$ faizahbafadhal@gmail.com, ${ }^{3}$ adesiska@ gmail.com
}

\begin{abstract}
Abstrak. Penelitian ini bertujuan untuk mengetahui strategi pemasaran politik kepala desa petahana di desa Sidomukti yang mampu mempertahankan kekuasaannya selama tiga periode. Penelitian ini menggunakan metode deskriptif kualitatif dengan melakukan wawancara dengan masyarakat desa, tim sukses, dan kepala desa petahana. Sebagaimana diketahui kepala desa memegang jabatan selama enam tahun dan dapat menjabat paling banyak tiga kali masa jabatan secara berturut-turut atau tidak secara berturut-turut. Kepala desa yang menjabat di desa Sidomukti saat ini mampu menduduki jabatan sebagai kepala desa selama tiga periode berturut-turut, tentu memerlukan strategi untuk dapat mempertahankan kedudukannya itu. Jika di analisa dengan teori 4p marketing politik yaitu produk, promosi, harga, dan penempatan. Pada produk Sutrisno menyalurkannya lewat visi misi dan program kerja. Pada promosi Sutrisno melakukan kampanye secara terus-menerus dan tidak terbatas pada waktu kampanye yang ditentukan. Pada harga sutrisno menjual kinerjanya yang sudah terbukti baik dalam membangun desa. Kemudian pada penempatan dengan melakukan pencitraan. Namun hal itu saja tidak cukup, sesuai dengan hasil penelitian Sutrisno diketahui melibatkan birokrasi pemerintahan desa untuk melakukan kampanye dan jaringan keluarganya yang cukup luas di Desa Sidomukti karena memiliki tiga orang istri yang terlibat kampanye politik untuk memenangkan Sutrisno.
\end{abstract}

\section{Kata kunci: Strategi, Marketing Politik, Kepala Desa Petahana}

Abstract. This study aims to determine the political marketing strategy of the incumbent headman in the village of Sidomukti who is able to maintain his power for three periods. This study used a qualitative descriptive method by conducting interviews with village communities, the success team, and the incumbent headman. As is well known, the headman holds a position for six years and can serve at most three consecutive terms of office or not. The headman who has served in Sidomukti village is currently able to hold the position of headman for three consecutive terms, of course, requires a strategy to be able to maintain this position. If analyzed with the $4 p$ theory of political marketing, namely product, promotion, price, and placement. Sutrisno's products distribute it through a vision, mission and work program. In the promotion, Sutrisno carried out campaigns continuously and was not limited to the specified campaign time. At the price Sutrisno sells his proven performance in building the village. Then on the placement by doing imaging. However, that alone is not enough, according to Sutrisno's research results, it is known that he involved the village government bureaucracy to carry out campaigns and his family network is quite extensive in Sidomukti Village because he has three wives who were involved in political campaigns to win Sutrisno.

Keywords: Strategy, Political Marketing, Incumbent Headman

\section{PENDAHULUAN}

Pemilihan kepala desa atau yang sering disingkat dengan istilah pilkades, merupakan bentuk praktik demokrasi langsung di pedesaan. Dalam praktik demokrasi langsung seperti ini yang terpenting dikedepankan adalah proses pemilihan yang memegang teguh tiga aspek penting, yaitu aspek kompetisi 
antar kontestan, partisipasi dan kebebasan. Aspek kompetisi berkaitan dengan orangorang yang mencalonkan diri sebagai kepala desa dan cara-cara yang dipakai untuk menjadikan mereka sebagai calon kepala desa. Aspek partisipasi berkaitan dengan pemahaman masyarakat terhadap pemilihan kepala desa, cara mereka merumuskan tipe kepemimpinan kepala desa dan model mereka membangun kesepakatan politik dengan para calon kepala desa. Anggota masyarakat yang berpartisipasi dalam proses politik, misalnya melalui pemberian suara, terdorong oleh keyakinan bahwa melalui kegiatan bersama itu kepentingan mereka akan tersalur atau sekurang-kurangnya diperhatikan. Aspek kebebasan erat kaitannya dengan suasana warga pemilih dalam menentukan pilihan politiknya kepada para calon kepala desa.

Tahap terpenting dalam proses pilkades bagi kandidat calon kepala desa adalah masa kampanye. Pada masa kampanye setiap kandidat berusaha untuk mempengaruhi masyarakat sebagai pemilih untuk mendukung mereka dan memberikan suara pada saat pelaksanaan pilkades. Guna mendukung usaha kandidat dalam mendapatkan suara dari masyarakat, setiap kandidat perlu melakukan pendekatan atau strategi yang jitu untuk memenangkan kontestasi dalam pilkades.

Dalam proses political marketing, dapat digunakan penerapan 4P bauran, yaitu produk (product), promosi (promotion), harga (price), dan penempatan (place). Keempat bauran pemasaran tersebut kemudian diemplementasikan menjadi serangkaian kegiatan kampanye politik. Kampanye menurut Kotler dan Roberto adalah sebuah upaya yang diorganisasi oleh satu kelompok (agen perubahan) yang ditujukan untuk memersuasi target sasaran agar bisa menerima, memodifikasi atau membuang ide, sikap dan perilaku tertentu. Sedangkan kampanye politik adalah sebuah peristiwa yang bisa didramatisasi.

\section{STRATEGI}

Strategi pada hakikatnya adalah perencanaan dan manajemen untuk mencapai tujuan, namun untuk mencapai tujuan tersebut, strategi tidak berfungsi sebagai peta jalan yang memberikan arah saja, melainkan harus mampu menunjukkan bagaimana taktik operasionalnya.

\section{MARKETING POLITIK}

Marketing politik bukan dimaksudkan untuk 'menjual' kontestan kepada publik, melainkan sebagai teknik untuk memelihara hubungan dengan publik agar tercipta hubungan dua arah yang langgeng. Teori marketing politik dalam proses political marketing, dapat digunakan penerapan 4P, yaitu:

Produk (product) yang ditawarkan institusi politik merupakan sesuatu yang kompleks, dimana pemilih akan menikmatinya setelah sebuah partai atau seorang kandidat terpilih. Arti penting sebuah produk politik tidak hanya ditentukan oleh karakteristik produk itu sendiri. Pemahaman pemilih juga memainkan peranan penting dalam memaknai dan menginterpretasikan sebuah produk politik. Produk ini berisi konsep, identitas ideologi. Baik dimasa lalu maupun sekarang yang berkontribusi dalam pembentukan sebuah produk politik.

Promosi (promotion) biasanya sebuah institusi politik melakukan promosi ide, platform partai dan ideologi selama kampanye pemilu. Tidak jarang institusi politik bekerjasama dengan sebuah agen iklan dalam membangun slogan, jargon dan citra yang akan ditampilkan. Perlu digarisbawahi disini bahwa sebenarnya promosi institusi politik tidak hanya terjadi semasa periode kampanye belaka. Aktivitas promosi harus dilakukan terus-menerus dan permanen dan tidak hanya terbatas pada periode kampanye saja.

Harga (price) mencakup banyak hal, mulai ekonomi, psikologi, sampai citra nasional. Harga ekonomi mencakup semua biaya yang dikeluarkan institusi politik selama periode kampanye. Suatu institusi politik berusaha untuk meminimalisasi harga produk politik (minimalisasi risiko) mereka dan meningkatkan (maksimalisasi) harga produk politik lawan. Menjadikan harga politik lawan semakin mahal (semakin berisiko) merupakan strategi yang bisa dilakukan institusi politik 
guna memperoleh dukungan publik, sebab pemilih akan memilih kontestan yang memiliki risiko atau harga relatif paling kecil.

Penempatan (place) berkaitan erat dengan cara hadir atau distribusi sebuah institusi politik dan kemampuannya dalam berkomunikasi dengan para pemilih. Sebuah institusi politik harus bisa mengidentifikasi dan memetakan struktur serta karakteristik masyarakat, baik itu secara geografis maupun demografis.

Sesuai dengan Undang Undang Pasal 39 ayat (1) dan (2) Nomor 6 Tahun 2014 Tentang Desa:

(1) Kepala Desa memegang jabatan selama 6 (enam) tahun terhitung sejak tanggal pelantikan.

(2) Kepala Desa sebagaimana dimaksud pada ayat (1) dapat menjabat paling banyak 3 (tiga) kali masa jabatan secara berturutturut atau tidak secara berturut-turut.

Dalam undang-undang ini telah diatur pembatasan maksimal periode jabatan kepala desa. Yang dimaksud dengan "terhitung sejak tanggal pelantikan" adalah seseorang yang telah dilantik sebagai kepala desa maka apabila yang bersangkutan mengundurkan diri sebelum habis masa jabatannya dianggap telah menjabat satu periode masa jabatan 6 (enam) tahun. Kepala desa yang telah manjabat satu kali masa jabatan diberi kesempatan untuk mencalonkan kembali paling lama 2 (dua) kali masa jabatan. Sementara itu, kepala desa yang telah menjabat 2 (dua) kali masa jabatan diberi kesempatan untuk mencalonkan kembali hanya 1 (satu) kali masa jabatan.

Desa Sidomukti merupakan salah satu desa yang ada di Kecamatan Dendang dan merupakan salah satu desa tertua, terhitung sejak tahun 1980 hingga sekarang telah terjadi beberapa kali pergantian kepemimpinan di Desa Sidomukti. Kepala Desa yang menjabat telah melewati dua kali masa jabatan dan terpilih kembali untuk ketiga kalinya. Berikut daftar perkembangan kepemimpinan di Desa Sidomukti.
TABEL 1.1

Perkembangan Kepemimpinan Desa Sidomukti

\begin{tabular}{|c|l|c|c|}
\hline No & \multicolumn{1}{|c|}{ Nama } & Tahun Menjabat & \\
\hline 1. & Sagiran & $1980-1983$ & KUPT \\
\hline 2. & Samsul Sidarni & $1983-1985$ & KUPT \\
\hline 3. & Suwarno & $1986-1987$ & Kepala Desa \\
\hline 4. & Sadiran & $1987-1990$ & Kepala Desa \\
\hline 5. & Edi susanto & $1990-1994$ & Kepala Desa \\
\hline 6. & Rochani & $1994-1999$ & Kepala Desa \\
\hline 7. & Sodikin & $1999-2004$ & Kepala Desa \\
\hline 8. & Sutrisno & $2007-2012$ & Kepala Desa \\
\hline 9. & Sutrisno & $2013-2019$ & Kepala Desa \\
\hline 10. & Sutrisno & $2020-2026$ & Kepala Desa \\
\hline
\end{tabular}

Sumber: File Profil Desa Sidomukti

Mata pencaharian sebagaian besar penduduk Desa Sidomukti adalah petani. Program kerja yang dilakukan kepala desa sangat mendukung mata pencaharian penduduk desa yaitu dibidang pertanian dengan program penanaman pohon pinang tahunan. Hal ini bisa menjadi daya tarik atau produk dari kepala desa untuk mempertahankan jabatannya dan mendapatkan dukungan terus menerus dari masyarakat selain dari kepemimpinan yang memuaskan dan ketokohan kepala desa yang baik.

Banyak kajian penelitian sebelumnya yang membahas tentang strategi marketing politik calon kepala daerah atau calon kepala desa. Salah satunya dilakukan Suwignyo Widagdo pada tahun 2016 dengan judul penelitian Peran Ketokohan, Ikatan Emosional, dan Program Kerja dalam Memengaruhi Perilaku Memilih (Pendekatan Pemasaran Politik dalam Pemilihan Calon Kepala Desa). Berdasarkan hasil penelitian yang dilakukan Suwignyo Widagdo secara parsial ketokohan dan ikatan emosional tidak memiliki pengaruh secara parsial terhadap perilaku memilih calon kepala desa. Namun demikian ketokohan, ikatan emosional dan program kerja memiliki pengaruh secara simultan terhadap keterpilihan calon kepala desa. Program kerja memiliki pengaruh yang dominan dibandingkan dengan variabel ketokohan dan ikatan emosional. Kondisi ini berbeda dengan hasil penelitian sejenis yang menunjukkan ketokohan dan ikatan emosional memiliki pengaruh yang signifikan. Hasil survei dilapangan memang menunjukkan bahwa pemilih (konsumen) tidak lagi menjadikan ketokohan dan ikatan emosional sebagai indikator utama dalam menentukan pilihan (pembelian). Program kerja atau 
kemaanfaatan dari produk yang akan dibeli dan dianggap sesuai dengan kebutuhannya, maka produk tersebut akan dipilih.

Pada penelitian ini yaitu tentang strategi marketing politik yang digunakan Kepala Desa Sidomukti Kecamatan Dendang Kabupaten Tanjung Jabung Timur. Di Desa Sidomukti saat ini kepala desa yang menjabat sudah dua kali berturut-turut terpilih menjadi kepala desa yaitu periode 2007-2012 dan 2013-2019, yang bersangkutan mencalonkan diri lagi dalam pilkades berikutnya dan memenangkannya. Sebelum terpilih sebagai kepala desa pada tahun 2007, pada pilkades sebelumnya beliau mencalonkan diri namun gagal. Namun, setelah terpilih menjadi kepala desa, beliau dapat melanggengkan masa jabatannya sebagai Kepala Desa Sidomukti selama tiga periode. Berikut tabel jumlah perolehan suara pada pilkades.

TABEL 1.2

Perolehan Suara Pilkades Tahun 2013

\begin{tabular}{|c|l|c|}
\hline No & \multicolumn{1}{|c|}{ Nama } & Perolehan suara \\
\hline 1. & Sutrisno & 1309 \\
\hline 2. & Abdul Salam & 352 \\
\hline 3. & Muajib & 217 \\
\hline
\end{tabular}

TABEL 1.3

Perolehan Suara Pilkades Tahun 2019

\begin{tabular}{|c|l|c|}
\hline No & \multicolumn{1}{|c|}{ Nama } & Perolehan suara \\
\hline 1. & Choirur Rozikin & 398 \\
\hline 2. & Sutrisno & 1492 \\
\hline
\end{tabular}

\section{METODE PENELITIAN}

Penelitian ini mengambil lokasi di Desa Sidomukti Kecamatan Dendang Kabupaten Tanjung Jabung Timur Provinsi Jambi. Penulis memperoleh data primer dengan melakukan wawancara dengan kepala desa petahana, tim sukses, dan masyarakat desa Sidomukti. Data sekunder diperoleh dari dokumen resmi desa Sidomukti.

\section{PEMBAHASAN}

Marketing politik dapat dipahami sebagai sebuah arena yang didalamnya terjadi pertukaran berbagai kerangka berpikir, teori, dan teknik pemasaran produk untuk memasarkan atau menawarkan janji kebijakan politik. Dalam marketing politik, yang ditekankan adalah penggunaan pendekatan dan metode marketing untuk membantu kandidat agar lebih efisien serta efektif dalam membangun hubungan dua arah dengan konstituen dan masyarakat.

\section{STRATEGI MARKETING POLITIK KEPALA DESA PETAHANA}

Seorang kandidat membutuhkan suatu perencanaan strategis dalam melakukan hubungan dengan masyarakat dan bisa juga dilihat bahwa pada akhirnya kebutuhan dan keinginan yang ditawarkan kandidat adalah hal-hal yang menyentuh seluruh lapisan masyarakat, kebutuhan sosial kemasyarakatan, kebutuhan untuk menyalurkan, kebutuhan masyarakat berpendapat, kebutuhan untuk sejahtera, berpendidikan, kesehatan, dan sebagainya. Perencanaan ini menyangkut produk politik yang akan dibawakan, image yang akan dimunculkan dan program kampanye yang akan dilakukan. Perencanaan perlu dilakukan agar alokasi sumber daya (manusia, keuangan, infrastruktur) dapat dilakukan secara efisien. Selain itu, perencanaan dibutuhkan agar setiap program dan aktifitas memiliki kesamaan dan arah.

\section{PRODUK}

Produk yang ditawarkan dalam politik merupakan sesuatu yang kompleks, di mana pemilih akan menikmatinya setelah seorang kandidat terpilih. Produk utama dari politik adalah platform yang berisi konsep, identitas ideologi, dan program kerja sebuah institusi politik. Selain itu, apa saja yang telah dilakukan institusi politik di masa lalu berkontribusi dalam pembentukan sebuah produk politik. Institusi politik menjual produk yang tidak nyata yang sangat terkait dengan sistem nilai yang didalamnya melekat janji dan harapan akan masa depan. Didalamnya terdapat visi yang bersifat atraktif yang berarti kepuasan yang dijanjikan tidaklah segera tercapai, tetapi hasilnya lebih bisa dinikmati dalam jangka panjang.

Produk yang ditawarkan pada kegiatan kampanye kepala desa petahana bersama tim 
sukses ialah dengan mempersiapkan produk politik berupa visi dan misi serta program kerja. Program kerja yang ditawarkan bersifat inovatif dan mementingkan aspek kehidupan masyarakat desa Sidomukti, mulai dari infrastruktur desa, meningkatkan perekonomian masyarakat, hingga perkembangan sumber daya manusia. Dimana program kerja yang dijanjikan memang terlaksana dengan baik dan kinerjanya sebagai kepala desa sudah berjalan dengan sebagaimana mestinya. Sehingga Ia dipercaya masyarakat untuk mengemban tugas sebagai kepala desa hingga tiga periode.

Dari visi misi dan program kerja yang mendukung, Sutrisno lebih menekankan kepada peningkatan sumber daya manusia masyarakat desa dan mengoptimalkan pelayanan kepada masyarakat oleh birokrasi pemerintahan desa.

Menyusun program kerja dengan memahami apa yang dihadapi, mengapa hal tersebut muncul serta bagaimana efeknya, akan membuat program kerja yang disusun lebih akurat, fokus, dan sesuai dengan kebutuhan masyarakat. Sehingga masyarakat memberikan suaranya pada saat pemilihan kepala desa, karena mereka menganggap program-program kerja yang ditawarkan mewakili keadaan masyarakat.

\section{PROMOSI}

Sebagai kepala desa petahana Sutrisno tidak hanya melakukan kampanye pada masa kampanye yang telah ditetapkan. Tetapi konsisten melakukan kampanye dari awal periode pertama menjabat sebagai kepala desa hingga akan mencalonkan diri kembali untuk periode ketiga. Proses kampaye tersebut dilakukan secara terus-menerus baik itu melalui media maupun dialog dalam forum formal atau informal dengan masyarakat.

Sutrisno menyampaikan pesan politiknya secara terus-menerus dan berulangulang agar mudah diingat oleh masyarakat. Karena image politik perlu didukung oleh konsistensi aktivitas politik jangka panjang, kampanye politik pun harus dilakukan secara permanen dan tidak terbatas pada waktu menjelang pemilihan saja. Sebelum dan setelah pemilihan juga berperan amat penting dalam pembentukan image politik yang nantinya akan memengaruhi perilaku pemilih dalam mengevaluasi kualitas para kontestan. Karena image politik yang telah terbangun melalui proses interaksi terus-menerus dengan masyarakat tidak mudah hilang dari memori kolektif masyarakat.

Sutrisno yang statusnya sebagai kepala desa petahana tentu mendapatkan keuntungan bagi dirinya untuk melakukan hidden promosi. Sutrisno dapat mencuri start untuk melakukan kampanye. Banyak juga keuntungan lain bagi kepala desa petahana salah satunya adalah ruang promosi yang lebih luas dibanding dengan rival politiknya. Mengingat namanya yang sudah dikenal oleh masyarakat ketimbang calon lain.

Komunikasi yang dilakukan tidak cukup satu arah, dari kandidat. Kandidat membutuhkan umpan balik atas informasi yang telah diberikan kepada masyarakat. Tidak hanya itu, komunikasi dua arah ini juga menuntut kandidat untuk memahami bagaimana reaksi masyarakat terhadap apa yang sudah dilakukannya. Kemudian kandidat harus mencari, manakah hal yang bisa diperbaiki berdasarkan masukan-masukan dari masyarakat. Agar dapat menciptakan kepuasan dan loyalitas pemilih, kandidat harus dapat mendengarkan suara dan aspirasi mereka. Selain itu, kandidat harus terbuka untuk menerima kritikan dan masukan yang ditujukan kepadanya.

Kemudian Sutrisno melakukan kampanye dengan teknik door to door yang diyakini dapat mampu meningkatkan elektabilitas calon kepala desa. Dengan teknik ini tim sukses mendatangi rumah penduduk dari pintu ke pintu untuk memastikan apakah masyarakat sudah mempunyai pilihan atau belum. Jika masyarakat belum memiliki pilihan, dapat dilakukan pendekatan sehingga akhirnya tertarik untuk memilih calon kepala desa yang ditawarkan. Kalau pun sudah punya pilihan namun masih dapat mengubah pilihan, maka perlu dilakukan persuasi sehingga bisa mengubah dukungannya.

Teknik door to door dipilih Sutrisno dan tim sukses untuk bertemu pemilih dalam 
kampanye pemilihan. Strategi ini terbukti bermanfaat bagi petahana untuk mempromosikan dirinya, sebelum masa kampanye. Strategi ini diyakini tim sukses Sutrisno paling ideal untuk menggaet suara. Sebab, cara kampanye door to door menggerakkan Sutrisno untuk lebih berkontribusi dengan melibatkan diri pada masalah lokal, organisasi dan komunitas.

\section{HARGA}

Jika hanya menyampaikan visi misi serta program kerja dan komunikasi hal itu saja tidak cukup karena saat ini masyarakat tidak akan terpengaruh jika hanya sebatas janji-janji politik belaka dan masyarakat lebih membutuhkan kerja nyata. Oleh karena itu Sutrisno 'menjual' hasil kerja nyatanya yang berhasil saat menjabat sebagai kepala desa dua periode sebelumnya.

Karena dengan puasnya masyarakat terhadap kinerja seorang kandidat, semakin besar pula keinginan masyarakat untuk mempertahankan hubungan jangka panjang. Begitu sebaliknya, ketika masyarakat kecewa terhadap kinerja seorang kandidat, akan berkurang pula tingkat kepercayaan publik terhadap kemampuan kandidat tersebut dalam menyelesaikan permasalahan yang terjadi.

Dengan adanya hasil kerja yang nyata dari visi misi serta program kerja Sutrisno dapat menjadi nilai plus dirinya dimata masyarakat dan akan mempengaruhi suara masyarakat terhadap dirinya pada saat pilkades berlangsung.

Dengan baiknya reputasi, seorang kandidat politik memiliki kemudahan untuk membuat masyarakat rela memberikan suara mereka kepadanya. Ketika kandidat tersebut memenangkan pemilihan, masyarakat akan yakin dan percaya melalui trade record bahwa kandidat tersebut dapat membawa daerah ke kondisi yang lebih baik.

\section{PENEMPATAN}

Penempatan berkaitan dengan erat dengan cara hadir atau distribusi sebuah institusi politik dan kemampuannya dalam berkomunikasi dengan para pemilih atau calon pemilih. Ini berarti sebuah institusi politik harus dapat memetakan struktur serta karakteristik masyarakat. Distribusi merupakan suatu jaringan yang berisi orang dan institusi yang terkait dengan aliran produk politik kepada masyarakat secara luas sehingga masyarakat dapat merasakan dan mengakses produk politik tersebut dengan lebih mudah.

Strategi marketing politik dengan menggunakan penempatan yang dilakukan Sutrisno adalah dengan cara menyampaikan jargon-jargon sederhana pada pertemuanpertemuan masyarakat, menyelipkan sedikit program kerja dan ajakan-ajakan secara terus menerus kepada masyarakat untuk memilihnya. Bentuk dari pertemuanpertemuan masyarakat itu dapat berupa kegiatan adat, keagamaan, atau kegiatan sosial di desa Sidomukti atau hanya pada kegiatan informal seperti duduk di warung.

Hadirnya Sutrisno dalam diskusidiskusi yang dilaksanakan oleh masyarakat tidak lain untuk menumbuhkan citra baik Sutrisno di mata masyarakat atau biasa dikenal dengan istilah pencitraan. Citra atau pencitraan diartikan sebagai kesan seseorang atau individu tentang sesuatu yang muncul sebagai hasil dari pengetahuan dan pengalamannya. Sehingga pencitraan yang dilakukan Sutrisno ketika Sutrisno sebagai calon kepala desa sering hadir dalam diskusi-diskusi masyarakat akan mampu menimbulkan persepsi di masyarakat bahwa sang calon merupakan orang yang akan mendengarkan aspirasiaspirasi masyarakat yang nantinya akan disampaikan demi kemajuan desa serta menimbulkan kesan dan pandangan positif kepada Sutrisno.

\section{SEGMENTASI}

Bentuk bauran dari teori marketing politik harus selalu memperhitungkan segmen dan kelompok-kelompok orang yang hendak dimasuki. Segmentasi merupakan kemampuan institusi politik mengidektifikasi kelompokkelompok yang terdapat dalam masyarakat. Dengan teridentifikasinya kelompokkelompok ini, institusi politik dapat memahami karakteristik di setiap kelompok masyarakat. Pemetaan bisa dilakukan secara demografis, di mana pemilih dikelompokkan 
berdasarkan tingkat pendidikan, pekerjaan, usia, kelas sosial, pemahaman akan dunia politik, kepercayaan agama, dan etnis. Pemetaan juga dilakukan berdasarkan keberpihakan pemilih, misalnya saja berapa pendukung tradisional, berapa pendukung partai atau kandidat lain, berapa jumlah massa mengambang (floating mass) dan mungkin juga berapa persentase golput.

Antara segmentasi dan positioning adalah dua hal yang tidak dapat dipisahkan satu dengan yang lain. Segmentasi sangat dibutuhkan untuk dapat mengidentifikasi karakteristik yang muncul di setiap kelompok masyarakat. Sementara positioning adalah upaya untuk menempatkan image dan produk politik yang sesuai dengan masing-masing kelompok masyarakat. Setiap kelompok masyarakat tersusun dari individu-individu yang memiliki ciri, kepribadian, harapan, aspirasi dan tujuan yang kurang lebih sama. Hal ini memudahkan dalam mengkomunikasikan pesan politik karena mereka semua berbagi hal-hal yang kira-kira seragam. Sekali disampaikan, pesannya akan dapat dicerna oleh individu-individu yang terdapat di dalamnya.

Tim sukses dari Sutrisno sudah melakukan pemetaan pendukungnya. Setiap dusun sudah dibentuk kader utama, yang tugasnya adalah mencari suara di setiap RT yang ada di setiap dusun. Selanjutnya kader akan membuat sebuah laporan rutin dimana sejauh mana suara yang akan memilih Sutrisno. Menjadi keunggulan dari cara berkampanye Sutrisno ini adalah menyasarnya tim pemenangan dengan cara membaur dengan lapisan masyarakat khususnya dari kaum pemuda. Hampir setiap kesempatan tim pemenangan hadir dan ikut di rapat-rapat rutin pemuda. Di dalam rapat tersebut tim pemenangan dan Sutrisno sendiri hadir dalam pemecahan masalah yang dihadapi. Selain masuk di karang taruna kepemudaan, tim Sutrisno juga sering berdiskusi dengan beberapa tokoh masyarakat akan adanya pemecahan masalah sosial yang dihadapi di lingkungan masyarakat. Sehingga pendekatan dilakukan secara kolektif terhadap kelompokkelompok masyarakat. Setiap kelompok masyarakat tersusun dari individu-individu yang memiliki ciri, kepribadian, harapan, aspirasi, dan tujuan yang kurang lebih sama.

\section{FAKTOR YANG MEMENGARUHI TERPILIHNYA KEMBALI KEPALA DESA PETAHANA}

Birokrasi biasanya ditempatkan sebagai alat kepentingan penguasa untuk mempertahankan kekuasaannya. Karena peranan birokrasi yang cukup kuat, pemihakan birokrasi kepada kekuatan politik atau pada golongan yang dominan telah membuat birokrasi tidak steril sehingga terjadinya kecurangan dalam pemilihan. Karena netralitas birokrasi merupakan fenomena lama yang senantiasa menjadi wacana aktual menjelang, saat, dan setelah pemilihan. Dalam kenyataannya masih banyak ditemukan keterlibatan birokrasi dalam pemilihan.

Sesungguhnya netralitas birokrasi merupakan hal yang perlu terus dijaga dan diawasi, agar proses pemilihan dapat berjalan secara jujur dan adil antara calon yang memiliki kekuasaan dengan calon yang tidak memiliki relasi kuasa dilingkungan pemerintahan.

Namun dari hasil penelitian di lapangan, ditemukan fakta bahwa yang menjadi tim sukses Sutrisno adalah semua kepala dusun yang ada di desa Sidomukti. Ada tiga dusun yang ada di desa Sidomukti yaitu Dusun Jaya Indah, Dusun Rejo Agung, dan Dusun Tanjung Sari. Dimana disetiap dusun terdapat RT, di dusun Jaya Indah terdapat 12 RT, dusun Rejo Agung terdapat 11 RT, dusun Tanjung Sari terdapat 9 RT.

Penentuan tim sukses Sutrisno tidak secara resmi dibentuk, melainkan ia mengisinya dengan orang-orang yang memang memiliki ikatan emosional yang kuat dengannya, orang-orang yang berdedikasi dan memiliki loyalitas yang tinggi kemudian berkomitmen. Karena memang biasanya tim sukses adalah orang dekat dan kepercayaan sang kandidat, tim sukses memegang peranan penting dalam kontestasi politik, dan dibentuk untuk menggalang suara sebesar-besarnya.

Proses perekrutan anggota tim sukses Sutrisno bukan didasari kemampuan yang dimiliki individu melainkan karena kedekatan 
emosional yang dimiliki antara birokrasi dan kepala desa, karena birokrasi memiliki posisi yang cukup strategis untuk menjadi mesin politik pemenangan kandidat pasangan calon karena dapat mendulang suara. Keterlibatan birokrasi yang cukup kuat dalam memberikan dukungan kepada petahana setidaknya dipengaruhi oleh dua hal. Pertama, imingiming naik jabatan atau naik promosi ketika nantinya terpilih. Kedua, posisi birokrasi yang cenderung dilematis.

\section{PENGARUH JARINGAN KELUARGA}

Dengan sistem kekeluargaan ini dapat dilihat bahwa keluarga memiliki peran penting dalam menyebarkan informasi tentang diri Sutrisno yang akan mencalonkan diri lagi sebagai kepala desa. Hubungan kekeluargaan berhasil membentuk ikatan pribadi yang kuat selama proses kampanye dilakukan.

Diketahui Sutrisno memiliki basis massa yang mapan dengan memiliki jaringan keluarga yang cukup besar yang tersebar di desa Sidomukti karena diperkuat dengan fakta bahwa Sutrisno memiliki tiga orang istri. Jika ketiga istrinya ikut terlibat dalam proses kampanye tentu sangat membantu Sutrisno dalam mendongkrak jumlah suaranya dalam pemilihan.

Jaringan kekeluargaan menjadi landasan menjadi landasan bagi Sutrisno untuk membangun basic dukungan. Sutrisno terlebih dahulu mencari dukungan kepada orang-orang yang masih memiliki hubungan kekeluargaan. Karena biasanya hubungan persaudaraan menjadi pertimbangan tertinggi dalam memilih. Hubungan keluarga yang solid dapat menciptakan kekompakan dan lebih mempersatukan persaudaraan dalam memenangkan seorang kandidat.

Sutrisno yang tumbuh dan besar di desa Sidomukti tentu memiliki sanak saudara yang cukup banyak baik dari jalur ayah atau ibunya, ditambah dengan tiga orang istri yang dimiliknya membuat jaringan keluarga Sutrisno menjadi lebih luas. Istri-istrinya tentu ikut dalam kegiatan kampanye dan mempengaruhi keluarganya untuk memilih Sutrisno dalam pilkades. Hal ini dapat dijadikan salah satu penyebab Sutrisno terpilih kembali menjadi kepala desa karena masyarakat cenderung memilih seseorang yang masih memiliki hubungan kekerabatan.

\section{KESIMPULAN}

Dalam pembahasan dan hasil penelitian mengenai strategi marketing politik kepala desa petahana pada pilkades di desa Sidomukti, maka penulis penyimpulkan bahwa:

a. Strategi politik yang dilakukan Sutrisno sebagai kepala desa petahana pada pilkades di desa Sidomukti dianalisa dengan dengan teori penerapan 4P strategi marketing politik yang dikemukakan dalam buku Firmanzah menunjukkan bahwa produk yang digunakan Sutrisno merupakan merumuskan visi misi dan program kerja yang sesuai dengan kebutuhan dan mewakili keadaan masyarakat desa. Promosi yang dilakukan Sutrisno adalah dengan melakukan kampanye secara terus menerus yang tidak hanya terbatas pada periode kampanye saja, Sutrisno konsisten melakukan kampanye melalui dialog dalam forum formal maupun informal dengan tujuan agar mudah diingat oleh masyarakat. Harga yang Sutrisno jual adalah hasil kerja nyatanya atau keberhasilannya dalam menerapkan program kerja pada saat menjabat dua periode sebelumnya hal itu menjadi nilai tambah dirinya dimata masyarakat, karena baiknya reputasi dan trade record Sutrisno mempengaruhi suara masyarakat terhadap dirinya. Penempatan yang dilakukan Sutrisno adalah dengan melakukan pencitraan dengan hadir dalam kegiatan adat, keagamaan, dan kegiatan sosial dan menyampaikan jargon-jargon sederhana dan menyampaikan ajakan kepada masyarakat untuk memilihnya.

b. Sutrisno dapat menjaga eksistensinya dengan terpilih kembali menjadi kepala desa Sidomukti untuk kali ketiga dipengaruhi oleh dirinya yang melibatkan birokrasi pemerintahan desa, dengan menjadikan tiga kepala dusun yang ada di desa Sidomukti tim sukses pemenangannya (kepala dusun Jaya Indah, Juwari; kepala dusun Rejo Agung, Achmad Fulhudi; 
kepala dusun Tanjung Sari, Badrus Syaifudin) kemudian faktor jaringan kekeluargaan yang luas karena Sutrisno memiliki tiga orang istri dan terlibat dalam kampanye untuk memenangkan Sutrisno di pilkades.

\section{SARAN}

Berdasarkan hasil penelitian yang telah dilakukan, maka penulis menyarankan bahwa untuk calon kepala desa maupun calon kepala daerah agar tidak melibatkan birokrasi dalam kegiatan kampanye dan politik. Terhadap masyarakat supaya memilih calon kepala daerahnya sesuai dengan kemampuan yang dimiliki kandidat.

Selanjutnya dari penelitian ini diharapkan mampu menambah wawasan masyarakat terutama yang ingin duduk menjadi kepala desa atapun kepala daerah dengan harapan dapat memahami dan juga mengimplemantasikannya. Dari sisi akademis juga diharapkan bisa menjadi bahan referensi dan rujukan pada penelitian strategi politik selanjutnya. Selain itu juga bisa menambah perkembangan ilmu di dalam lingkungan politik.

\section{DAFTAR PUSTAKA}

Arif, Muhammad. "Strategi Political Marketing Kandidat dalam Pilkades (Studi Kasus Kemenangan M. Fauzi pada Pilkades Desa Sungai Ara Kecamatan Kempas Kabupaten Indragiri Hilir Tahun 2015"), artikel Universitas Abdurrab.

Budiarjo, Miriam. (2013). Dasar-Dasar Ilmu Politik. Jakarta: PT Gramedia Pustaka Utama.

Chandra, Hafied. (2014). Komunikasi politik Konsep, Teori, dan Strategi. Jakarta: Rajawali Pers.

Firmanzah. (2012). Marketing Politik: Antara Pemahaman dan Realitas. Jakarta: Yayasan Obor Indonesia, 2012.

Maschab, Mashuri. (2013).Politik Pemerintahan Desa di Indonesia. Yogyakarta: PolGov.

Peraturan Menteri Dalam Negeri Republik Indonesia No. 112 Tahun 2014, tentang Pemilihan Kepala Desa.
Satori, Djam'an.(2017). Metodologi Penelitian Kualitatif. Bandung: Alfabeta. Sayuti, Solatun Dulah. (2014). Komunikasi Pemasaran Politik. Bandung: PT Remaja Rosdakarya.

Scruton, Roger. (2013). Kamus Politik. Yogyakarta: Pustaka Pelajar.

Sugiyono. (2017).Metode Penelitian Kuantitatif, Kualitatif, dan $R \& D$. Bandung: Alfabeta.

Undang-Undang No. 6 Tahun 2014 tentang Desa.

Wasesa, Silih Agung. (2013). Political Branding \& Public Relations. Jakarta: PT Gramedia Pustaka Utama.

Widagdo, Suwignyo. (2016). "Peran Ketokohan, Ikatan Emosional dan Program Kerja dalam Memengaruhi Perilaku Memilih (Pendekatan Pemasaran Politik dalam Pemilihan Calon Kepala Desa)”, STIE Mandala, Jember, 2016.

Widjaja. (2005). Otonomi Desa. Jakarta: PT. Raja Grafindo Persada. 